\title{
Relationship of interest read with skills of living provide novel students of class VIII private vocational school 3
}

\author{
E Afriyona', ${ }^{1}$ Samadhan ${ }^{2}, \mathbf{E ~ G a n i}^{3}$ \\ \{esa.afriyona@yahoo.com, syahrulr@fbs.unp.ac.id ${ }^{2}$, erizal.gani@ fbs.unp.ac.id ${ }^{3}$ \} \\ ${ }^{1,2,3}$ Universitas Negeri Padang, Jl. Prof. Dr. Hamka Air Tawar Padang Sumatera Barat 25131, Indonesia
}

\begin{abstract}
The background of the problem in this study is the lack of student awareness of the importance of reading and the lack of students' ability to listen specifically to listening to snippets of novels. This type of quantitative research uses the correlation method. The population and sample in this study were class VIII students of SMPN 3 Pangkalan Koto BaruSubdistrict which consisted of 4 classes totaling 108 people, while the sample in this study were 28 people, with sampling using a claster random sampling technique. Based on the results of data analysis and discussion, the following results are obtained. First, the average reading interest of class VIII students of SMPN 3 Pangkalan Koto BaruSubdistrict, which is 74 in the range of $66-75 \%$ with qualifications more than enough. Second, the average skill of listening to the novel footage of class VIII SMPN 3 Pangkalan Koto BaruSubdistrict is 80 which is in the range of $76-85 \%$ with good qualifications. Third, there is a significant relationship between the two variables because tcount is greater than t table, which is $2.361>2.056$ with $n-2(28-2=26)$ and a significant level of 0.05 . From the results of the correlation it can be concluded that there is a significant relationship between interest in reading with the skill of listening to the novel footage of class VIII students of SMPN 3 Pangkalan Koto Baru District.
\end{abstract}

Keywords: Reading interest, novels, vocational school

\section{Introduction}

Language is one aspect that distinguishes between one ethnic group and another. Humans in interacting need language as a communication tool in the form of symbols or signs that always contain thoughts, meanings, ideas, ideas and feelings of someone. Regarding the use of language, there are four basic language skills, namely listening, speaking, reading and writing skills. Four skills are used as a communication process. Between each other influence and are interconnected. The four language skills cannot be separated from one another, because to be a good speaker, must be a good listener and to be a good writer, must be a good reader. Therefore, these four reading skills support each other to be able to achieve the objectives of learning Indonesian [1,2].

Reading interest is one of the important factors that must be grown for students when they have to master reading skills. Reading interest as a tendency of the soul to be obtained in stages to respond selectively, positively, and accompanied by a sense of satisfaction with 
specific things that are read. If you are interested in reading, you will seriously read the reading that you are interested in to get information or other purposes of reading $[2,3]$.

Based on initial observations the author obtained information about several factors regarding reading interest (1) lack of encouragement from teachers or the surrounding environment about the importance of reading, (2) limited means due to collection of reading in the library is still limited, (3) reading material that is not interesting, so students prefer to read humor stories, comics and newspapers rather than reading works of fiction, (4) lack of student awareness of the importance of reading, (5) wifehat's time to read to library [5,6]. Listening skills are an important factor for students' success in learning at school, listening to our frequent encounters in life, one of which is in school all students are required to listen to what the teacher is talking about, because by listening they can learn lessons and understand what the teacher is saying. One of the listening skills that is of concern to students is the skill of listening to the trailer snippets. The teacher at the school reads a sample of the novel, the student will determine the intrinsic element of the novel's footage. However, many students do not understand or understand what they see, so the low listening skills of the novels read by the teacher because the class atmosphere is not conducive so that what the teacher conveyed is not well absorbed[7,8].

Based on these explanations, researchers are interested and want to investigate further about this problem. It needs to be done to determine the extent of reading interest, learning students in learning Indonesian, especially the skills of listening to novels in SMPN 3, Pangkalan Koto Baru District.

\section{Method}

The method used in this study is the correlation method. Correlational descriptive is research that is designed to determine the level of relationship of different variables in a population which aims to determine how much influence the variable $\mathrm{X}$ on the $\mathrm{Y}$ variable and the shape of the relationship that occurs[4]. The population in this study were eighth grade students of SMPN 3 Pangkalan Koto Baru Subdistrict totaling 108 students. So in the sampling of this study the authors used cluster random sampling technique, the study sample was obtained, namely class VIII.3 which numbered 28 students.

The variable in this study, namely reading interest with the skill of listening to samples of novels of class VIII students of SMP Negeri 3, Pangkalan Koto BaruSubdistrict. The variables in this study are the independent variables and the dependent variable which becomes the $\mathrm{X}$ variable (independent variable), namely the reading interest and the $\mathrm{Y}$ variable (the dependent variable), namely the skill of listening to the trailer sample. The independent variable is estimated to have an effect on the dependent variable whereas the dependent variable will be influenced by the independent variable. The relationship between the independent variable and the dependent variable in this study is reading interest with the skill of listening to the trailer snippets. The research research instruments used in this study were two, namely questionnaires and subjective tests.

\section{Result and Discussion}

\subsection{Interest in reading class viii students of smpn 3 pangkalan koto baru district}

The results of the measurement of reading interest in the indicators of the benefits of reading with an average value of 82.46 are included in the good qualifications because they are in the range of values of $76-85 \%$. The average reading value is more important than other 
activities 69.25 including qualifications more than enough because it is in the range of 66$75 \%$. The average score trying to get material reading 71.86 , including in qualifications, is more than enough because it is in the range of $66-75 \%$. The average value of using the time to read 74.60 including qualifications is more than enough because it is in the range of $66-75 \%$. The average reading interest for all 74.28 indicators is in the range of $66-75 \%$ with qualifications more than enough.

3.2Skill of listening to novel excerpts of class viii students of smpn 3 pangkalan koto baru district

The average listening to novel footage seen from the figure indicator is 99 with perfect qualifications which are in the range of $96-100 \%$. The average listening to novel footage seen from the characterization indicators is 87 with excellent qualifications which are in the range of $86-95 \%$. The average listening to novel footage seen from the theme indicator is 58 with sufficient qualifications which are in the range of 56-55\%. The average listening to novel footage seen from the background indicator is 71 with more than enough qualifications which are in the range of $66-75 \%$. The average listening to novel footage seen from the flow indicator is 75 with more than enough qualifications which are in the range of $66-75 \%$. The average score of students in listening to novel skills for all indicators is 80 with good qualifications which are in the range of $76-85 \%$.

\subsection{Relationship to reading interest with skill of listening to novel footage}

The following is known the level of relationship between reading interest and the level of skill in listening to the novel footage of class VIII students of SMPN 3 Pangkalan Koto Baru District. To determine the value of the reading interest variable $(\mathrm{X})$ and the variable of the novel snippet listening skill (Y) will be correlated.

The calculation of the correlation coefficient between reading interest and listening skills for novel footage can be seen as follows.

$$
\begin{gathered}
=\frac{\frac{N \sum X Y-\left(\sum X\right)\left(\sum Y\right)}{\sqrt{\left\{N \sum X^{2}-\left(\sum X\right)^{2}\right\}\left\{N \sum Y^{2}-\left(\sum Y\right)^{2}\right\}}}}{28.161545-(2085)(2240)} \\
=\frac{4523260-4670400}{\sqrt{\left\{28.157643-(2085)^{2}\right\}\left\{28.174750-(2240)^{2}\right\}}} \\
=\frac{-147140}{\sqrt{-102395345700}}=\frac{-147140}{\sqrt{\{66779\}\{-4528300\}}} \\
=0,420 \\
=\frac{-147140}{-349904.85}
\end{gathered}
$$

Table 1.Value interpretation

\begin{tabular}{cl}
\hline \multicolumn{1}{c}{$\mathrm{R}$} & interpretation \\
\hline between 0,800 to 1,000 & High \\
between 0,600 to 0,800 & Enough \\
\hline
\end{tabular}




\begin{tabular}{ll}
\hline between 0,400 to 0,600 & Rather low \\
between 0,200 to 0,400 & Low \\
between 0,000 to 0,200 & Very low \\
\hline
\end{tabular}

Second, from the time that you use are rated practicality of $83.33 \%$ with a very practical category. Based on the value of $\mathrm{r}=0.420$, the correlation coefficient between reading interest and the listening skills of the novels of class VIII students of SMPN 3 Pangkalan Koto Baru Subdistrict showed a rather low correlation. This can be seen in the interpretation table $\mathrm{r}$ value. The value of $r=0.420$ lies in the range of 0.400 to 0.600 which is low. Therefore, the next step of analyzing the data is to test the hypothesis by using the t-test formula as follows.

$$
\begin{gathered}
t=\frac{r \sqrt{n-2}}{\sqrt{1-r^{2}}} \\
t=\frac{0,420 \sqrt{28-2}}{\sqrt{1-0,420^{2}}} \\
t=\frac{0,420 \sqrt{26}}{\sqrt{1-} 0,1764} \\
t=\frac{0,420.5,099}{0,8236} \\
t=\frac{2141.58}{0,907}
\end{gathered}
$$

$t=2,361$

After the value of $\mathrm{t}$ is obtained, the next step is to compare the value of $\mathrm{t}$ count with $\mathrm{t}$ table at a significant level of 0.05 with the degree of freedom n-2. For more details, can be seen in the following table.

Table 2. Hypothesis test reading interest with skill of listening to novel snippets

\begin{tabular}{llll}
\hline $\mathrm{R}$ & $\mathrm{Th}$ & $\mathrm{Nn}-2$ & $\mathrm{Tt}$ \\
\hline & & & $\mathrm{P} 0,05$ \\
0,420 & 2,361 & 26 & 2,056 \\
\hline
\end{tabular}

From the results of testing the hypothesis, it can be concluded that there is a significant relationship between Reading Interest and the Skill of Listening to Novel Class VIII Students in SMPN 3 Pangkalan Koto Baru District. Thus, H0 in this study is rejected while H1 is accepted because the test results prove that tcount is greater than table, which is 2.361 $<2.056$.

\section{Conclusions}

Based on the data description, data analysis and discussion on the relationship of reading interest with listening skills to the novel footage of class VIII students of SMPN 3 Pangkalan Koto Baru Subdistrict can be concluded as follows: First, the reading interest of class VIII 
students of SMPN 3 Pangkalan Koto Baru Subdistrict is in qualification more than enough because it is in the range of $66-75 \%$ with the acquisition of an average value of 74 . Second, the listening skills of novels of class VIII students of SMPN 3 Pangkalan Koto Baru Subdistrict are in good qualification because they are in the range of $76-85 \%$ with the acquisition of an average value of 80 . Third, there is a significant relationship between interest in reading by listening to novels of class VIII students of SMPN 3 Pangkalan Koto Baru District because tcount is greater than ttable which is $2,361>2,056$.

\section{References}

[1] Salom L G and Monreal C S 2009 Interacting with The Reader: Politeness Strategies in Engineering Research Article Discussion (Murcia: International Journal of English Studies) pp. 175-189.

[2] Geske A and Ozola A 2008 Factor Influencing Reading Literacy at The Primary School Level Vol. 6 (Latvia: Problems of Education in The 21th Century) pp. 71-77

[3] Guillen M T F and Bermejo M L G 2011 Creative Writing for Language,Content and Literacy Teaching Vol. 4 (Madrid: International Education Studies) pp. 39-46

[4] Arikunto, Suharsimi, Research Procedures A Practice Approach. Yogyakarta: Rineka Cipta,2006.

[5] Malloy, J. A., Marinak, B., \& Gambrell, L. (Eds). (2010). Essential readings on motivation. Newark, DE: International Reading Association.

[6] Considine, D., Horton, J., \& Moorman, G. (2009, March). Teaching and reaching the millennial generation through media literacy. Journal of Adolescent \& Adult Literacy, 52(6), 471-481. doi: 10.1598/JAAL.52.6.2

[7] Chastain, K.. The Development of Modern Language Skills: Theory to Practice. Philadelphia: Center for Curriculum Development,1971.

[8] Steinberg, S. An Introduction to Communication Studies. Juta and Company Ltd,2007.

[9] Priyatni, Endah Sari, Reading Literature with Critical Literacy. Jakarta: Bumi Aksara,2012.

[10] Rahmawati, Fitri, Quick Motion Mastering Indonesian Literature. East Jakarta: Laskar Aksara, 2015. 